\title{
Are South African print newspaper narratives reframed for Internet news portals or not?
}

\author{
Ilse Feinauer \\ Department of Afrikaans and Dutch, Stellenbosch University, South Africa \\ E-mail: aef@sun.ac.za
}

\begin{abstract}
This paper deals with the translation of newspaper texts from Afrikaans/English newspapers for Afrikaans/English Internet news portals. In this paper I discuss to what extent newspaper reports, selected for translation and subsequent publication on the Internet, undergo a reframing process and how these reports are edited, rewritten, reshaped and repackaged (transformed) for a new cultural context (Bielsa and Bassnett 2009). This study has a sociological and cultural perspective in that it deals with Baker's (2006) narrative frame model in detecting which narrative frames can be identified in the translation of these texts from South African newspapers for a more global readership. Baker sees framing as an active strategy that implies agency through which translators consciously participate in the construction of reality within a specific socio-cultural group. The way in which and the reasons why the news teams for the Internet news portals (re)direct or reframe the perspective of reality as constituted within South African print newspapers is the main research topic.
\end{abstract}

Keywords: news translation, transediting, narrative frame model, print newspapers, e-news platforms, ideology

\section{Introduction}

This paper deals with the transcreation, or rather transediting, of news texts from print newspapers for News24 and Nuus24/Netwerk24, respectively English and Afrikaans multilevel digital platforms. News24 was established 12 years ago as the main Internet news platform for Media24, which is a division of Naspers, one of the oldest South African Afrikaans- and Afrikaner-oriented publishers of magazines and newspapers. The Afrikaans Internet news portal Nuus 24 was established in September 2010 and replaced by Netwerk24 in July 2013. In this paper I investigate the extent to which print news reports, selected for translation and subsequent publication on the Internet, undergo a reframing process. I also investigate how these reports are edited, rewritten, reshaped and repackaged (transformed) into a new context (Bielsa and Bassnett 2009:11). 
This study has a sociological perspective in that it deals with Baker's (2006) narrative frame model. Its aim is to detect which narrative frames can be identified in the translation and adaptation of texts from a print newspaper genre to an Internet genre for a more global readership, or at least for a more technologically-advanced South African readership. Narrative theory and framing are used to investigate the ways in which translators highlight, weaken or transform aspects of the narrative(s) encoded in the source text (ST). Baker (2006:106) sees (re)framing as an active strategy that implies agency through which (in this case specifically) editors consciously participate in the construction of reality. Gambier (2006) suggests that media frames focus on what is discussed and how it is (or is not) discussed. According to Tymoczko (2007), translators (read 'editors') can be effective activists and empowered agents of social change.

This article can be read alongside two publications, Van Rooyen and Naudé (2009) and Van Rooyen (2011). In these publications the authors investigate the transediting processes taking place in adjusting texts by the South African Press Association (SAPA) for the news bulletins of OFM News (Van Rooyen and Naudé 2009), and describe the functioning of translation in the radio newsroom of Radio Sonder Grense (RSG), the Afrikaans service of the South African Broadcasting Corporation (SABC) (Van Rooyen 2011). In both these articles the authors illustrate how Nord's functionalist model, and more specifically her looping model, can be used to mediate in a multicultural newsroom. In this article, the way in which the news teams of News24 and Nuus24/Netwerk24 (re)direct the perspective of reality as constituted within Afrikaans and English print newspapers is the main research topic. It links more closely to a paper by Chen (2009) in which he investigates the construction of 'self' and 'other' in the transediting of news texts concerning political conflicts.

\section{Contextualisation of the newspaper group}

Naspers - short for Nasionale Pers ('National Press') - has grown from an organisation founded in 1915 with the primary goal of publishing the newspaper De Burger, a local Western Cape daily newspaper. Other newspapers followed suit, and magazine and book-publishing operations were founded. Naspers's print-media operations have developed over the years to such an extent that Naspers is now one of the leading media groups in Africa. With the advent of electronic media, Naspers expanded its activities in the 1980s to incorporate pay-television and, later, Internet platforms. By 1990 its products covered the whole of South Africa, with newspapers, magazines and books in most of the 11 official languages. In 2000 Naspers organised and branded its print media businesses under the Media24 umbrella, and to simplify its group structure, Naspers consolidated all of its print media, book publishing and private education under Media24 in 2005 (History and Development 2010).

The daily newspapers Die Burger, Beeld and Volksblad have remained Afrikaans, but these days they are not so much focussed on white and Afrikaner readers. They have adapted fairly seamlessly to the new South Africa, with the newspapers now assuming the role of watchdog for minority groups and being some of the main critics of the ANC regime. They have indeed come a long way since 1948, when Die Burger started playing the role of "spokes newspaper" for the then-governing National Party and its infamous policy of apartheid. From the 1980s onwards and during the 1990s in particular, these ties were gradually severed, and Naspers and its publications started committing themselves to a new national unit encompassing all the people of South Africa. 
The English newspapers used as STs are City Press and The Witness. First published in 1982 as Golden City Press, City Press is a Sunday newspaper aimed at black readers. Its name was changed in 1983, and Media24 acquired the paper in 1984. South Africa's oldest newspaper, The Witness, serves English readers throughout KwaZulu-Natal, with most of its readers in inland KwaZulu-Natal. Owned by Media24, it was formerly known as the Natal Witness. These newspapers were chosen intentionally because they belong to Media24. By only selecting offshoots of Media24, no variation in company ideology is introduced, even though different publications are investigated as STs (mediaclubsouthafrica 2011).

The players investigated here within this social field of media discourse are the editorial teams and journalists of the original Afrikaans and English newspapers, the editorial teams and transeditors of News24 and Nuus24/Netwerk24, as well as the readerships of both the source and target news texts. Data were collected from all these sources. Source text readers of the Afrikaans newspapers are primarily Afrikaans-speaking and reside in metropolitan areas. They include mostly white and some coloured male and female South Africans from a middle to higher socio-economic class, in the age group 35 and older. The daily readership of the biggest Afrikaans print paper, Die Burger, is 550 000, which adds up to 3.3 million a week (Average issue readership of newspapers and magazines profile 2009). Source text readers of the biggest English newspaper used here, City Press, are primarily English-speaking and reside in metropolitan areas. They are mostly black females from a middle to higher socio-economic class, in the age group 25 and older. The readership for this Sunday newspaper amounts to 1867000 a week.

The target text (TT) readership for News24 is primarily local South African readers who access their news electronically, South Africans travelling locally and internationally, as well as expatriates. They are from a higher socio-economic class and mostly white metropolitan English- and Afrikaans-speakers (Internet users, international travellers, highly schooled and skilled), in the age group 30 and older. To a lesser extent, News24 is also read by an international readership with special interest in South Africa. Daily readership figures are 200,000. During March 2010, for instance, 2.4 million people, of which 1.7 million were local, accessed the site (Momberg 2010).

The TT readership for Nuus24/Netwerk24 is primarily (90\%) local Afrikaans South African readers who access their news electronically, Afrikaans South Africans travelling locally and internationally, as well as Afrikaans expatriates. They are from a higher socio-economic class and are mostly white, male, metropolitan Afrikaans-speakers (Internet users, international travellers, highly schooled and skilled), in the age group 30 and older. Monthly readership figures are 360,000 - more or less 12,000 a day (Oldewage 2011). Keep in mind that Nuus24 was only launched in September 2009.

\section{Theoretical base}

According to Johnson and Ensslin (2007:13), "in their function as public agencies of observation, interpretation, performance, representation and dissemination, the media exhibit a variety of signifying practices, which are unconditionally purpose-driven. Depending upon their particular point of emphasis, media producers therefore combine 'conative', 'emotive' and 'conceptual' meanings so as to achieve a maximum effect on the target audience". This can be linked to Fox (2009), who claims that so-called "objective reality" is superseded by a 
constructed reality unique to the paper and its readers. A process of constant recall of 'common knowledge' (knowledge shared only by the newspaper and its readers) leads readers to assume as factual knowledge what is in fact the discursive end established by the newspaper. Since news organisations are socially, culturally and politically situated, the so-called "suitable" and "acceptable" texts published in any newspaper, whether translated from a news agency or sourced and written as original texts by local journalists, are by no means completely neutral accounts of facts, but rather constitute a reality that has been constructed from the favoured perspectives of the news organisation.

This constructed reality is presented in the form of a narrative which is usually framed in a specific way. According to Baker (2006), human knowledge is narrative in nature and is therefore inclined to represent a particular perspective. There is no neutral ground, no neutral knowledge and consequently no neutral translation. Every translation is in one way or another a re-narration and a re-telling of the source text. Journalists and media translators can resort to various strategies to strengthen or undermine specific aspects of the narratives they mediate. Baker (2006:106) defines framing as "an active strategy that implies agency and by means of which we consciously participate in the construction of reality" (own emphasis). This means that the same set of events can be framed in different ways to promote competing or even complementary narratives. Baker (2006:107) refers to this as frame ambiguity, and this is what is investigated in this article. There is always a decision that needs to be taken on how the report on what is said or written should be interpreted and (re)presented, while the agents remain fully aware of the fact that these narratives would have specific effects on the diverse parties. We must remember that, just like some discourses are defined by the commentary on them, journalism is also a form of commentary. This commentary can be adjusted according to the ideological frames of newspapers by, for instance, omitting, adding or giving more relevance to some parts.

Baker's $(2006,2007)$ literature was developed as part of the sociological turn in Translation Studies. She investigates the ways in which translators and interpreters emphasise, undercut or modify narrative aspects in STs. Different framing strategies are used in the transcreation process, and by doing this, the transediting team takes part in the reconstruction of sociological and ideological reality. According to Baker (2006:3), narrative theory "[r]ecognizes that people's behaviour is ultimately guided by the stories they come to believe about the events in which they are embedded, rather than by their gender, race, colour of skin, or any other attribute". Narrative is defined by the "[p]ublic and personal stories we tell ourselves, not just those we explicitly tell other people, about the world(s) in which we live" (Baker 2006:19).

Baker's (2006, 2007:151) model of analysis mainly relies on the concept of narrative as seen within the fields of social and communication theory, rather than narratology or linguistics. "Narratives" are defined as 'public and personal stories' that present and construct our perceptions of the world (see also Fisher 1984, 1985, 1987; Bruner 1991 and Somers and Gibson 1994). Baker (2006:38) adds that, whether the motivation is commercial or ideological, translators and interpreters play a decisive role in articulating and contesting the full range of public narratives circulating within and around any society at any moment in time. 


\section{Data analysis}

Media or news frames focus on what is discussed and how it is (or is not) discussed. By the framing of news discourse, the editing team creates a context for their readers. News frames provide a context in which to understand issues, shape the inferences made, reinforce stereotypes, determine judgements and decisions and draw attention to some aspects of reality while obscuring other elements (Gambier 2006:11). To what extent does news undergo a reframing process by means of the translation or transediting process? To what extent does a transeditor reproduce, change or adapt the frames? (Gambier 2006:12). According to Baker (2006:105), transeditors (in this case, the editing teams of News24 and Nuus24/Netwerk24) face ethical choices with every assignment to either reproduce existing ideologies as encoded in the narratives elaborated in the text or utterance, or to dissociate themselves from those ideologies or frames. Translators/editors resort to specific strategies to support or undercut particular aspects of the narratives they mediate - explicitly or implicitly.

For this type of study, narrative theory could enable the researcher to conceptualise an identity in the TT which is, for example, not local and culture-specific, but more universal or global (culture-generic). One could even apply the frame of the 'Us vs. Them-polarisation' (Van Dijk 1998 in Chen 2009), where narratives framed within the Us-perspective could be used for the STs, and the TTs could be reframed to be read and understood by the Others - those outsiders not belonging to the South African, and specifically the Afrikaner or Afrikaans-speaking, community. If this were the case, it would mean, as Bielsa and Bassnett (2009:2) put it, that "[i]nformation that passes between cultures through news agencies is not only 'translated' in the interlingual sense, it is reshaped, edited, synthesized and transformed for the consumption of a new set of readers". This reshaping of information can also be seen as decontextualisation and then recontextualisation to fit the target reader.

\subsection{News24 - Afrikaans into English}

The content for News 24 and Nuus24/Netwerk24 is adapted or recreated text taken from local or international news agencies. It involves intralingual translation (English into English, or Afrikaans into Afrikaans) as well as interlingual translation (from Afrikaans/English newspaper articles originally written in Afrikaans/English, and then translated into English/Afrikaans). The interlingual translations are done by freelance translators translating fairly closely to the STs. The TTs are then repackaged by the editorial teams of News24 and Nuus24/Netwerk24, i.e. intralingual translation. As Kang (2007:221) puts it: "this involves using language strategically to convey special meanings and to project certain images deliberately".

One hundred and twenty randomly-chosen news reports were analysed: Afrikaans STs and English TTs as they appeared on the Internet as part of the news coverage of News24. Of these, only two texts were completely rewritten or transcreated to such an extent that the rewriter's name was added to that of the ST journalist. For the majority of texts it was more a case of transediting with less radical changes, since the readerships do not differ greatly on a cultural level. The lexis were for example not stripped of any cultural implications to be built up from scratch to fit the specific culture of the target reader. If this were the case, Gopinathan (2006:236) would refer to this adaptation process as transcreation. The editorial team and not the translators as such adopted the role of interventionists. The modifications were not in the first instance done to better suit the needs of the receivers, but rather to carry an ideological 
message. These choices made by the editing team boil down to how certain values and ideas are constructed or framed. These changes are much more subtle, but ideologically speaking, they are much more far-reaching. Fairclough (1995:25) sees media discourse as a social field of both ideological processes and linguistic processes, and a definitive relationship between these two processes exists in the sense that the linguistic choices made in the texts carry ideological meaning.

To what extent then were the English texts that appeared on the news platform News 24 framed differently from their Afrikaans counterparts?

\subsubsection{Translation strategies}

On a basic level, notions of place, space and time were reconfigured in the process of transediting. Only parts of the message to which the target readership could relate were transferred, and this was done in such a way that the relevance to them was enhanced. These strategies added to the reframing of the texts for the News 24 reader. From the specific types of adaptations applied to the STs, one can deduce that this news platform is not primarily meant for South Africans using News24 as their primary local newspaper. One of the main strategies applied is omission. Many of the reports were seriously shortened by the omission of information regarded as non-newsworthy, non-essential, or too local. Locality was not regarded as essential, e.g. burial information and specific addresses of where something had happened were omitted. Locality is important for the Afrikaans newspapers since they are focused on specific areas in South Africa: Burger focuses on the Western, Eastern and Northern Cape; Beeld focuses on Gauteng, Limpopo, and North-West; and Volksblad focuses on the Free State and Northern Cape.

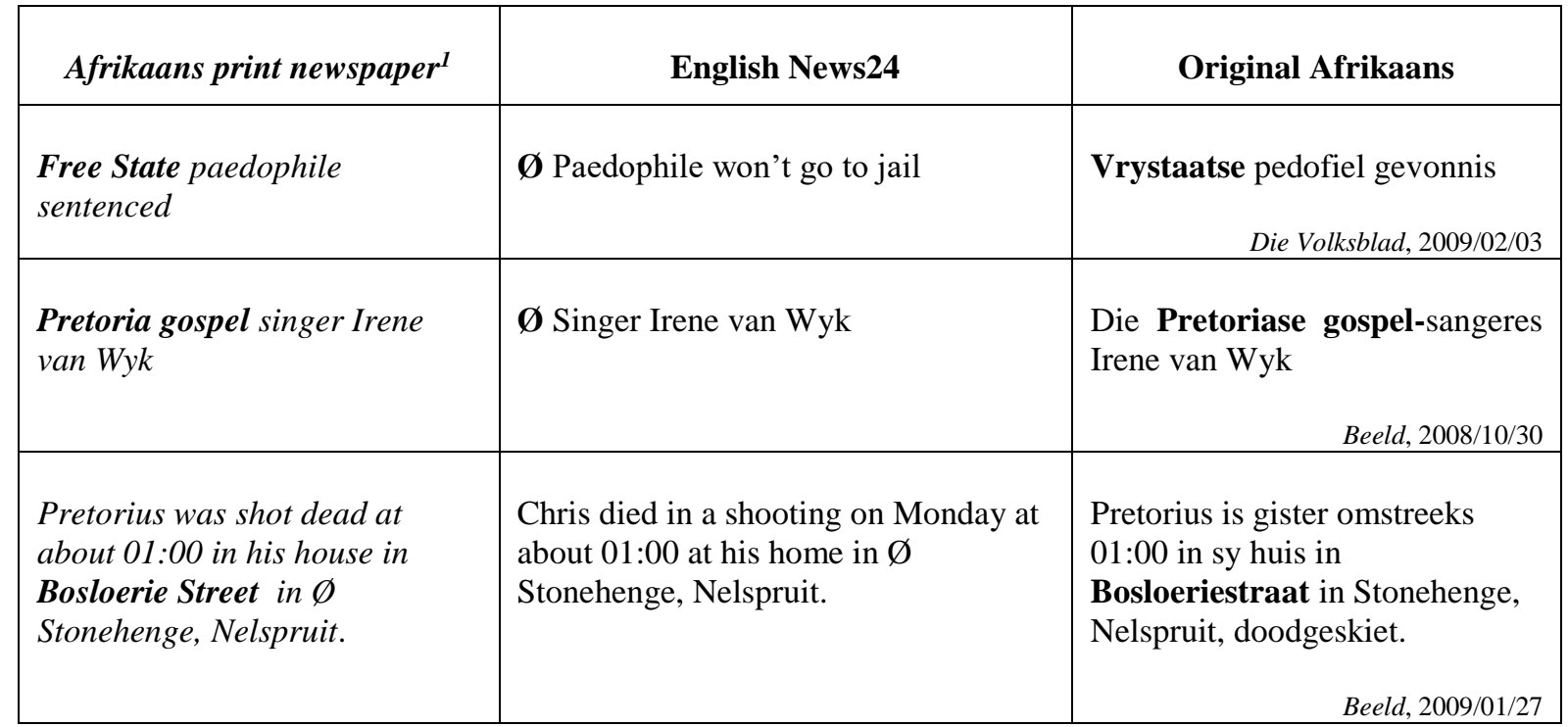

\footnotetext{
${ }^{1}$ English translations are supplied for the original Afrikaans texts throughout.
} 


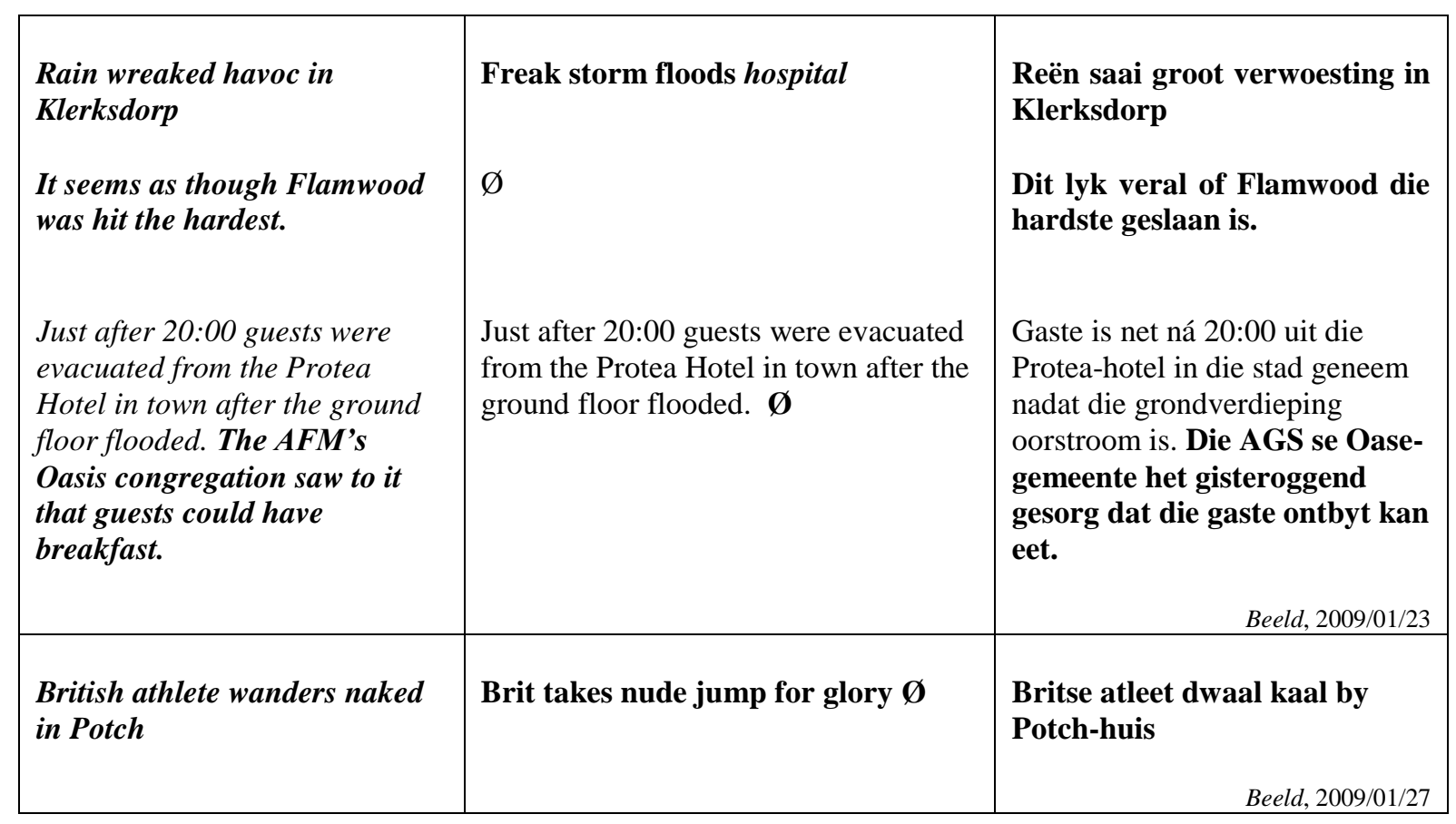

Some of the choices made during the transediting could be considered as purely linguistic, but they are not only linguistic; they also contribute to the narrative. Just by the omission of one abbreviation and by changing the active voice into passive, a narrative can be intentionally reframed to appeal to more readers. The following heading was adapted to suggest that the wellknown businessman Johan Rupert had been involved in a car crash instead of his son driving one of Rupert senior's cars:

\begin{tabular}{|l|c|l|}
\hline \multicolumn{1}{|c|}{ Afrikaans print newspaper } & English News24 & \multicolumn{1}{c|}{ Original Afrikaans } \\
\hline $\begin{array}{l}\text { Rupert Jr. did not write off } \\
\text { Ferrari }\end{array}$ & Rupert Ø Ferrari not written off & $\begin{array}{l}\text { Rupert jr. het toe nié Ferrari } \\
\text { afgeskryf nie }\end{array}$ \\
\hline
\end{tabular}

From the meagre use of explicitation (addition) as a strategy, one can deduce that the intended reader is well acquainted with South Africa. Explicitation is mainly used for the names of smaller opposition political parties and acronyms, mainly abbreviated in the printed newspapers, but fully written-out on the Internet. The ANC (African National Congress), however, was kept abbreviated: 


\begin{tabular}{|c|c|c|}
\hline Afrikaans print newspaper & English News24 & Original Afrikaans \\
\hline $\begin{array}{l}\text { Ms Rose Gudhluza, ID } \\
\text { chairperson in Gauteng ... } \\
\text { because he admitted to the } \\
\text { Mail and Guardian that he had } \\
\text { forged the signatures of } \\
\text { prominent people while he was } \\
\text { chief of Geda. }\end{array}$ & $\begin{array}{l}\text { Rose Gudhluza, Independent } \\
\text { Democrats chairperson in Gauteng ... } \\
\text { because he admitted to the Mail and } \\
\text { Guardian that he had forged the } \\
\text { signatures of prominent people while he } \\
\text { was chief of the Gauteng Economic } \\
\text { Development Agency (Geda). }\end{array}$ & $\begin{array}{l}\text { Me. Rose Gudhluza, OD- } \\
\text { voorsitter in Gauteng, het gister } \\
\text { by die Johannesburgse sentrale } \\
\text { polisiekantoor 'n klag van } \\
\text { bedrog teen Niehaus gelê omdat } \\
\text { hy aan die Mail \& Guardian } \\
\text { beken het dat hy as Geda-hoof } \\
\text { hoëlui se handtekeninge vervals } \\
\text { het. }\end{array}$ \\
\hline & & Beeld, 2009/02/16 \\
\hline $\begin{array}{l}\text { Mr Ryan Coetzee, } \boldsymbol{D A} \mathbf{M P}, \\
\text { said the ANC would rather } \\
\text { look after corrupt cadres than } \\
\text { eradicate the problem. }\end{array}$ & $\begin{array}{l}\text { Ryan Coetzee, Democratic Alliance } \\
\text { MP, said the ANC would rather look } \\
\text { after corrupt cadres than eradicate the } \\
\text { problem. }\end{array}$ & $\begin{array}{l}\text { Mnr. Ryan Coetzee, DA-LP, het } \\
\text { gesê die ANC sal eerder na } \\
\text { korrupte kaders omsien as om } \\
\text { dié probleem uit te roei. }\end{array}$ \\
\hline & & Beeld, 2009/02/16 \\
\hline
\end{tabular}

In only one case did the editor think the Internet reader might not be as well informed as the reader in South Africa, and Afrikaans singer was added to the name of Steve Hofmeyr. The identities of other well-known Afrikaans singers, preachers and ex-sportspeople, however, are not explained (e.g. Kurt Darren, Angus Buchan and Joost van der Westhuizen).

In some instances, extra information that might interest the English reader was added:

\begin{tabular}{|c|c|c|}
\hline Afrikaans print newspaper & English News24 & Original Afrikaans \\
\hline $\begin{array}{l}\text {... when he threw a cup of tea } \\
\text { in the face of Esmaré } \\
\text { Weideman, editor of } \\
\text { Huisgenoot. }\end{array}$ & $\begin{array}{l}\ldots \text { when he threw a cup of tea in the } \\
\text { face of Esmaré Weideman, editor of } \\
\text { Huisgenoot, YOU and Drum. }\end{array}$ & $\begin{array}{l}\ldots \text { waarin hy 'n koppie tee in die } \\
\text { gesig van me. Esmaré } \\
\text { Weideman, redakteur van } \\
\text { Huisgenoot, gegooi het. }\end{array}$ \\
\hline & & Beeld, 2008/12/22 \\
\hline
\end{tabular}

Here the English magazines were added to the Afrikaans title, which is the only one that appears in the Afrikaans ST.

The main reason I believe that target readers are primarily South African is that cultural words and phrases are mostly kept in Afrikaans and transferred without any explicitation. This would indeed seem very foreign to a non-South African reader, and even to a reader with very little knowledge of Afrikaans: 
'Fear of swart gevaar drove Nel' (Heading)

(swart gevaar means "black danger")

... Nel could not handle his fear of the "swart gevaar".

... this fear of black people had changed into hatred of the "swart gevaar".

The Garsfontein High School support team, which includes a psychologist, also called two dominees to the school to assist with counselling.

(dominees means "ministers/reverends")

He ran to Chris's bedroom where he and his wife Karenita, 38, were sleeping. "Oom Chris jumped up and ran past me. As he went through the door, shots rang out."

(This story was told by a nephew of Chris. The foreign oom ('uncle') was not kept as a description of family relationship but rather as a respectful form of address used by Afrikaans-speakers to address older men.)

In one instance, a word borrowed from isiZulu was also transferred:

Because of the illegal occupation, the people had never before complained about the lack of facilities. This was raised by the community at an imbizo on Wednesday.

(An imbizo is a meeting, usually called together by a traditional leader. It is nowadays used as a general term for meetings where the community is involved.)

Only once was a transferral from Afrikaans explained. The reason for this might be that the news concerned FW de Klerk, in whom a larger number of international readers would be interested. Slapgat was explained by spineless person, but slapgat is much more offensive than spineless person. It literally translates into "lame arse". 


\begin{tabular}{|c|c|c|}
\hline Afrikaans print newspaper & English News24 & Original Afrikaans \\
\hline Pik's son calls $F W$ a slapgat & Pik's son slams 'slapgat' FW & Pik se seun noem FW 'n 'slapgat' \\
\hline $\begin{array}{l}\text { One of former minister Pik } \\
\text { Botha's sons has called F.W. de } \\
\text { Klerk a "slapgat" because he } \\
\text { walked out of the Government } \\
\text { of National Unity (GNU). }\end{array}$ & $\begin{array}{l}\text { One of former minister Pik Botha's } \\
\text { sons has called FW de Klerk a } \\
\text { "slapgat" (spineless person) because } \\
\text { he abandoned the Government of } \\
\text { National Unity (GNU). }\end{array}$ & $\begin{array}{l}\text { 'n Seun van oudmin. Pik Botha het } \\
\text { oudpres. F.W. de Klerk 'n } \\
\text { "slapgat" genoem omdat hy uit } \\
\text { die regering van nasionale eenheid } \\
\text { gestap het. }\end{array}$ \\
\hline $\begin{array}{l}\text { Botha said he used to have lots } \\
\text { of respect for De Klerk, but not } \\
\text { anymore, referring to his (De } \\
\text { Klerk's) "slapgat" behaviour } \\
\text { which he showed by walking } \\
\text { out of the GNU. }\end{array}$ & $\begin{array}{l}\text { Botha said he used to have a lot of } \\
\text { respect for De Klerk, but that was no } \\
\text { longer the case because of his (De } \\
\text { Klerk's) "slapgat" behaviour in } \\
\text { abandoning the GNU. }\end{array}$ & $\begin{array}{l}\text { Hy het baie respek vir De Klerk } \\
\text { gehad, maar nie meer nie en het na } \\
\text { sy (De Klerk se) "slapgatgeit" } \\
\text { verwys wat hy openbaar het deur } \\
\text { uit die RNE te stap. } \\
\text { Burger, 2009/01/30 }\end{array}$ \\
\hline
\end{tabular}

Right from the heading, this report is reframed so that the negativity against De Klerk seems harsher than in the Afrikaans report. The Afrikaans heading translates to 'Pik's son calls FW a 'slapgat', whereas the English heading describes FW as being slapgat. Where the Afrikaans report states twice that De Klerk 'walked out' of the Government of National Unity, the English report states twice that De Klerk 'abandoned' the Government of National Unity.

\subsubsection{Ideological reframing}

The example above illustrates how the choice of lexical elements can lead to a more ideological influence on the reader, in this case a more negative perception of former president FW de Klerk. This shows that, on a deeper level, textual material can be selectively appropriated or manipulated by omissions, additions, accentuations or enhancements of particular aspects of a narrative encoded in the ST as part of the larger narrative(s) in which it is embedded (Baker 2006:114). The reports published in English in News24 were rechanneled according to an ideological agenda which seems less apparent in the Afrikaans STs. Compared to the Afrikaans newspapers, in News24 a much more negative image of post-1994 South Africa is portrayed. This concerns issues of crime, politics and racial issues which were intensified during the transediting process. This constructed reality is maintained throughout and is reinforced by the omission, distortion or misrepresentation of facts where necessary. The adaptations serve to confirm and reinforce News24's seemingly pre-established discourse, namely the intensification of crime, racial issues and the political situation regarding the ANC government.

In some articles, only the headings are adapted to intensify the horror of the various crimes. 


\subsubsection{Crime}

\begin{tabular}{|l|l|l|}
\hline \multicolumn{1}{|c|}{ Afrikaans print newspaper } & \multicolumn{1}{c|}{ English News24 } & \multicolumn{1}{c|}{ Original Afrikaans } \\
\hline $\begin{array}{l}\text { Farmer dies when he tried to } \\
\text { stop three robbers }\end{array}$ & Robbers shoot feisty farmer & $\begin{array}{l}\text { Boer sterf toe hy drie rowers wou } \\
\text { keer }\end{array}$ \\
\hline Kidnapping nightmare & 3 women survive horror attack & Ontvoer-nagmerrie \\
\hline
\end{tabular}

In others, the heading as well as the introductory sentence are adapted by adding information:

\begin{tabular}{|l|l|l|}
\hline \multicolumn{1}{|c|}{ Afrikaans print newspaper } & \multicolumn{1}{|c|}{ English News24 } & \multicolumn{1}{c|}{ Original Afrikaans } \\
\hline $\begin{array}{l}\text { Man who lost arm under } \\
\text { train under train thinks } \\
\text { robbers pushed him }\end{array}$ & Man pushed from train, loses arm & $\begin{array}{l}\text { Man wat arm onder trein } \\
\text { verloor dink rowers het hom } \\
\text { uitgestamp }\end{array}$ \\
$\begin{array}{l}\text { I must be dreaming, maybe it's } \\
\text { only a nightmare }\end{array}$ & $\begin{array}{l}\text { A man who was pushed out of a train } \\
\text { and lost his arm, says he lay on the } \\
\text { platform at Benoni station thinking } \\
\text { that he must be dreaming, or maybe it } \\
\text { was a nightmare }\end{array}$ & $\begin{array}{l}\text { Ek droom seker, dis dalk net 'n } \\
\text { nagmerrie. }\end{array}$ \\
\hline
\end{tabular}

In some others, this is achieved by reordering information and changing the passive voice into the active voice to intensify the horror of the event: 


\begin{tabular}{|c|c|c|}
\hline Afrikaans print newspaper & English News24 & Original Afrikaans \\
\hline $\begin{array}{l}\text { Student is fighting for his life } \\
\text { after taxi hits and drags him }\end{array}$ & 'Drunk' taxi driver hits student & $\begin{array}{l}\text { Student veg om sy lewe ná taxi } \\
\text { hom tref en sleep }\end{array}$ \\
\hline $\begin{array}{l}\text { He was so glad to be at } \\
\text { university that his whole } \\
\text { personality has changed. }\end{array}$ & $\begin{array}{l}\emptyset \text { A taxi driver has been arrested } \\
\text { after he hit a 19-year-old on a } \\
\text { pedestrian crossing. }\end{array}$ & $\begin{array}{l}\text { Hy was so bly om op } \\
\text { universiteit te wees dat sy hele } \\
\text { persoonlikheid verander het. }\end{array}$ \\
\hline $\begin{array}{l}\text { Therefore Mr Zwaai Kruger } \\
\text { found it so difficult to believe } \\
\text { that his } 19 \text {-year-old son is now } \\
\text { in intensive care in the Netcare } \\
\text { Greenacres hospital fighting } \\
\text { for his life after he was hit by a } \\
\text { taxi and dragged for nearly } 30 \\
m \text {. }\end{array}$ & $\begin{array}{l}\text { Jason Kruger is fighting for his life in } \\
\text { Netcare Greenacres Hospital after the } \\
\text { taxi rammed into him while he was } \\
\text { on the crossing at Admiralty and } \\
\text { University roads on his bicycle on } \\
\text { Tuesday afternoon. The first-year BA } \\
\text { student at Nelson Mandela } \\
\text { Metropolitan University (NMMU) was } \\
\text { dragged behind the vehicle for nearly } \\
30 \text { metres. }\end{array}$ & $\begin{array}{l}\text { Daarom is dit vir mnr. Zwaai } \\
\text { Kruger van Sedgefield moeilik } \\
\text { om te glo dat sy } 19 \text {-jarige seun } \\
\text { nou in die waakeenheid van die } \\
\text { Netcare Greenacres-hospitaal om } \\
\text { sy lewe veg nadat hy deur 'n } \\
\text { taxi getref en byna } 30 \mathrm{~m} \text { ver } \\
\text { gesleep is. }\end{array}$ \\
\hline $\begin{array}{l}\text { Jason, a first-year BA student } \\
\text { from NMMU who matriculated } \\
\text { last year from Knysna High, } \\
\text { was seriously injured when he } \\
\text { was hit by a taxi on Tuesday. } \\
\text { He was crossing Admiralty and } \\
\text { University roads on his bicycle } \\
\text { at a pedestrian crossing } \\
\text { around } 17: 00 \text { when he was hit } \\
\text { by the taxi. The taxi driver, } \\
\text { apparently under the } \\
\text { influence of alcohol, was } \\
\text { arrested on the scene. }\end{array}$ & $\begin{array}{l}\text { The taxi driver, who was presumably } \\
\text { intoxicated, was arrested on the scene. }\end{array}$ & $\begin{array}{l}\text { Jason, 'n BA-eerstejaarstudent } \\
\text { aan die Nelson Mandela } \\
\text { Metropolitaanse Universiteit } \\
\text { (NMMU) wat verlede jaar aan die } \\
\text { Hoërskool Knysna gematrikuleer } \\
\text { het, is ernstig beseer toe hy } \\
\text { Dinsdag deur 'n taxi getref is. } \\
\text { Hy het die voetoorgang by die } \\
\text { kruising van Admiraliteits- en } \\
\text { Universiteitsweg omstreeks 17:00 } \\
\text { op sy fiets oorgesteek toe die taxi } \\
\text { hom getref het. Die } \\
\text { taxibestuurder, wat } \\
\text { vermoedelik onder die invloed } \\
\text { van alkohol was, is op die toneel } \\
\text { in hegtenis geneem. }\end{array}$ \\
\hline & & Burger, 2009/02/26 \\
\hline
\end{tabular}

In other articles, the lexical items chosen throughout the target article add to the terror described in the ST: 


\begin{tabular}{|c|c|c|}
\hline Afrikaans print newspaper & English News24 & Original Afrikaans \\
\hline $\begin{array}{l}\text { Elderly person handled roughly } \\
\text { when ring did not come off }\end{array}$ & Robbers try bite ring off finger & $\begin{array}{l}\text { Bejaarde getakel toe ring nie } \\
\text { afkom }\end{array}$ \\
\hline $\begin{array}{l}\text { Ms Sheila Huart and her best } \\
\text { friend ms Petra Baxter (62) were } \\
\text { held up by two armed men in } \\
\text { their security complex in } \\
\text { Ontdekkerspark on the West- } \\
\text { Rand. }\end{array}$ & $\begin{array}{l}\text { Sheila Huart and her best friend Petra } \\
\text { Baxter (62) were attacked by two } \\
\text { armed robbers in their townhouse } \\
\text { complex. }\end{array}$ & $\begin{array}{l}\text { Me. Sheila Huart en haar beste } \\
\text { vriendin, me. Petra Baxter (62), } \\
\text { is in hul veiligheidskompleks in } \\
\text { Ontdekkerspark aan die Wes- } \\
\text { Rand deur twee gewapende } \\
\text { mans oorval. }\end{array}$ \\
\hline $\begin{array}{l}\text { My mother's face was nearly } \\
\text { destroyed. }\end{array}$ & $\begin{array}{l}\text { My mother's face was nearly beaten } \\
\text { to a pulp. }\end{array}$ & $\begin{array}{l}\text { My ma se gesig is byna } \\
\text { vernietig. }\end{array}$ \\
\hline Alleged sex network uncovered & Child sex network uncovered & $\begin{array}{l}\text { Beweerde seksnetwerk in VS } \\
\text { oopgevlek }\end{array}$ \\
\hline $\begin{array}{l}\text { An alleged sex network of child- } \\
\text { molesting, pornography and } \\
\text { possibly also rape of which } \\
\text { many small children apparently } \\
\text { were victims has been uncovered } \\
\text { in this town. }\end{array}$ & $\begin{array}{l}\text { An alleged sex network involving } \\
\text { pornography, the sexual abuse of } \\
\text { children and the possible rape of } \\
\text { many small children has been } \\
\text { uncovered in this Free State town. }\end{array}$ & $\begin{array}{l}\text { 'n Beweerde seksnetwerk van } \\
\text { kindermolestering, } \\
\text { pornografie en moontlik ook } \\
\text { verkragting waarin talle klein } \\
\text { kinders glo die slagoffers was, } \\
\text { is op dié dorp oopgevlek. }\end{array}$ \\
\hline $\begin{array}{l}\text { The police have confiscated } \\
\text { computers and four cell phones } \\
\text { that were allegedly used to } \\
\text { widely distribute pornography, } \\
\text { as well as other pornographic } \\
\text { material such as videos and } \\
\text { DVDs. It is not yet known } \\
\text { whether some of this was child } \\
\text { pornography and it was sent } \\
\text { away for forensic analysis. }\end{array}$ & $\begin{array}{l}\text { The police have confiscated computers } \\
\text { and four cell phones that were } \emptyset \text { used } \\
\text { to widely distribute pornography, as } \\
\text { well as other pornographic material } \\
\text { such as videos and DVDs. } \varnothing\end{array}$ & $\begin{array}{l}\text { Die polisie het op rekenaars en } \\
\text { vier selfone waarmee } \\
\text { pornografie glo wyd } \\
\text { rondgestuur is, sowel as ander } \\
\text { pornografiese materiaal soos } \\
\text { video's en DVD's beslag gelê. } \\
\text { Dit is nog nie bekend of } \\
\text { daarvan kinderpornografie is } \\
\text { nie en dit is vir forensiese } \\
\text { ontleding weggestuur. }\end{array}$ \\
\hline & & Volksblad, 2008/11/14 \\
\hline
\end{tabular}

In most of the Internet articles, subheadings were added to help steer the reader more quickly through the article or to guide the reader to a specific paragraph. These subheadings were chosen in such a way as to summarize the contents of the article. In doing so, the horror of the events is perceived as even more shocking, since there are no added modalities or other modifying mechanisms.

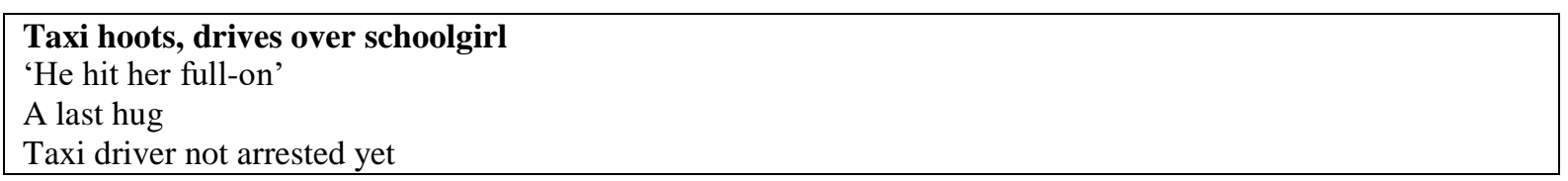

The following two instances were the only cases in which the horror of two murders were tempered in the News24 articles when compared to the Afrikaans STs. 
In one article, only the heading was adapted:

\begin{tabular}{|l|l|l|}
\hline \multicolumn{1}{|c|}{ Afrikaans print newspaper } & English News24 & Original Afrikaans \\
\hline $\begin{array}{l}\text { Murdered when he wanted to } \\
\text { help }\end{array}$ & 'Help, I've been shot!' & $\begin{array}{r}\text { Vermoor toe hy wil help } \\
\text { Beeld, } 2009 / 01 / 19\end{array}$ \\
\hline
\end{tabular}

In the second article, both the heading and introductory sentences were adapted by reordering the information in the source article:

\begin{tabular}{|c|c|c|}
\hline Afrikaans print newspaper & English News24 & Original Afrikaans \\
\hline $\begin{array}{l}\text { N14 murder: woman wants to } \\
\text { leave country }\end{array}$ & 'I held his hand for 45 minutes' & N14-moord: vrou wil landuit \\
\hline $\begin{array}{l}\text { 'I am angry, very angry.' After } \\
\text { the cold-blooded murder of } \mathrm{Mr} \\
\text { Dieter Fürrutter (65) of } \\
\text { Roodepoort, his wife Rosie (50), } \\
\text { is very seriously considering } \\
\text { leaving the country, although } \\
\text { she calls it her home. The } \\
\text { murder was the worst of a } \\
\text { series of crimes her family had } \\
\text { suffered. }\end{array}$ & $\begin{array}{l}\text { A man has told how he held his } \\
\text { friend's hand for } 45 \text { minutes while } \\
\text { waiting for the police to arrive, after } \\
\text { the friend was shot while helping him } \\
\text { with his broken down car. }\end{array}$ & $\begin{array}{l}\text { 'Ek is kwaad, baie kwaad." } \\
\text { Ná die koelbloedige moord } \\
\text { vandeesweek op mnr. Dieter } \\
\text { Fürrutter (65) van Roodepoort } \\
\text { oorweeg sy vrou, Rosie (50), dit } \\
\text { nou baie sterk om die land te } \\
\text { verlaat, al noem sy dit haar huis. } \\
\text { Dié moord was die ergste van 'n } \\
\text { reeks misdade waaronder haar } \\
\text { gesin al deurgeloop het. }\end{array}$ \\
\hline & & Beeld, 2009/01/22 \\
\hline
\end{tabular}

\subsubsection{Politics}

In Afrikaans newspapers, very offensive obscenities are never written out in full, whereas News24's policy is to write them out. Just by this strategy, the negative impact of the contents can be heightened. Compare the following two incidents involving people from various races where the racial issues were intensified in News24. The first article was about a young white male who went on a rampage shooting black people in an informal settlement. News24 also added information not found in the Afrikaans report. 


\begin{tabular}{|c|c|c|}
\hline Afrikaans print newspaper & English News24 & Original Afrikaans \\
\hline 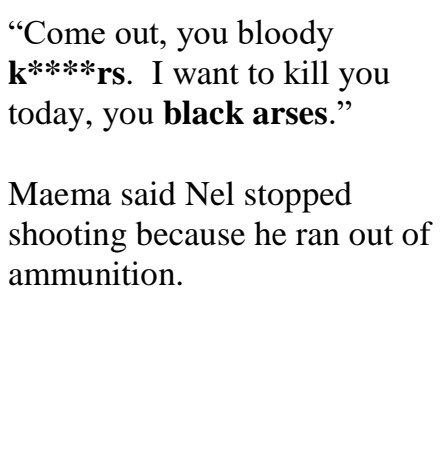 & $\begin{array}{l}\text { "Come out, you bloody kaffirs. I want } \\
\text { to kill you today, you black bastards." } \\
\text { Maema said Nel stopped shooting } \\
\text { because he ran out of ammunition. } \\
\text { According to the charge sheet Nel } \\
\text { had fired at least } 125 \text { rounds. When } \\
\text { he ran out of ammunition, he went to } \\
\text { farmers in the area and asked for } \\
\text { more ammunition. They refused to } \\
\text { help him }\end{array}$ & $\begin{array}{l}\text { "Kom uit, julle bleddie } \mathbf{k} * * * \mathbf{r s} \text {. } \\
\text { Ek wil julle vandag doodmaak, } \\
\text { julle swart gatte." } \\
\text { Volgens Maema het Nel } \\
\text { opgehou skiet omdat sy } \\
\text { ammunisie opgeraak het. } \\
\text { Beeld, 2008/11/20 }\end{array}$ \\
\hline
\end{tabular}

The actions of the notorious VIP-protection units of ANC political leaders, usually consisting of black policemen, were intensified by the use of terror in the heading as well as the writingout of the obscenities:

\begin{tabular}{|l|l|l|}
\hline \multicolumn{1}{|c|}{ Afrikaans print newspaper } & \multicolumn{1}{|c|}{ English News24 } & \multicolumn{1}{c|}{ Original Afrikaans } \\
\hline $\begin{array}{l}\text { When I say *** out of the } \\
\text { road, you have to *** out of } \\
\text { the road! }\end{array}$ & Blue light terror for motorist & $\begin{array}{l}\text { 'As ek sê *** uit die pad moet jy } \\
\text { uit die pad ***!' }\end{array}$ \\
\hline $\begin{array}{l}\text { When I say *** out of the road, } \\
\text { you have to *** out of the } \\
\text { road! }\end{array}$ & $\begin{array}{l}\text { "When I say fuck off out of the road, } \\
\text { you have to fuck off out of the road!" }\end{array}$ & $\begin{array}{l}\text { manneer jy uit die pad f* } \mathrm{f}^{* * *} \text { uit die pad, } \\
\text { meeld, 2009/02/26 }\end{array}$ \\
\hline
\end{tabular}

An article that mostly focuses on the various opposition parties was translated fairly close to the ST, but when a referral to the ANC's power was made, much more negative words were used in the News24 version:

\begin{tabular}{|l|l|l|}
\hline \multicolumn{1}{|c|}{ Afrikaans print newspaper } & \multicolumn{1}{c|}{ English News24 } & \multicolumn{1}{c|}{ Original Afrikaans } \\
\hline $\begin{array}{l}\text { According to him people } \\
\text { should vote for Cope because } \\
\text { it was the only party since the } \\
\begin{array}{l}\text { democratic transition that can } \\
\text { take away the power of the } \\
\text { ANC. }\end{array}\end{array}$ & $\begin{array}{l}\text { He said people should vote for Cope } \\
\text { because it was the only party since the } \\
\text { democratic transition that can break } \\
\text { the ANC's stranglehold. }\end{array}$ & $\begin{array}{l}\text { Cope stem omdat dit die enigste } \\
\text { party sedert die demokratiese } \\
\text { oorgang is wat die mag by die } \\
\text { ANC kan afneem. }\end{array}$ \\
Burger, 2009/02/02 \\
\hline
\end{tabular}

Carl Niehaus, former ambassador to the Netherlands and spokesperson for the ANC, was accused of stealing money, forging signatures of other dignitaries to get more money, being unable to pay his debt, and littering his CV with "lies and misrepresentations". During the apartheid regime, Niehaus and his former wife had been jailed for their political actions as members of the ANC. Under ANC rule he was taken up into the party "cadres", divorced his former wife and was married twice to black women, living a life of luxury. The newspapers 
lapped up the fall of Niehaus, but once again, his shame and demise are greatly intensified in the reworked articles in News24. After the heading, there are four short paragraphs in the ST regarding his resignation as spokesperson for the ANC, his redeployment to a new job in the ANC, and the ANC's lack of awareness of everything being revealed in the press and by Niehaus himself. All of this is omitted in the TT, and the News 24 article starts with the next sentence in the ST:

\begin{tabular}{|c|c|c|}
\hline Afrikaans print newspaper & English News24 & Original Afrikaans \\
\hline Carl Niehaus resigns & More Niehaus lies revealed & Carl Niehaus bedank \\
\hline Introduction & Introduction omitted & $\begin{array}{l}\text { Mnr. Carl Niehaus, gewese } \\
\text { ANC-woordvoerder, het } \\
\text { gisteraand uit sy nuwe werk in } \\
\text { die ANC bedank nadat nóg van } \\
\text { sy leuens aan die lig gekom het. } \\
\text { Hy bly egter 'n lid van die ANC, } \\
\text { het me. Jessie Duarte, ANC- } \\
\text { woordvoerder bevestig. } \\
\text { Die ANC het sy bedanking } \\
\text { aanvaar. Niehaus is Vrydag uit } \\
\text { sy pos as woordvoerder na 'n } \\
\text { nuwe pos in die ANC geskuif. } \\
\text { Me. Lindiwe Zulu, 'n ander } \\
\text { ANC-woordvoerder, het vroeër } \\
\text { gesê die ANC "was nie bewus } \\
\text { van alles wat nou deur die media } \\
\text { en Carl self op die tafel geplaas } \\
\text { is nie". }\end{array}$ \\
\hline $\begin{array}{l}\text { Another string of lies by } \\
\text { Niehaus became known. }\end{array}$ & $\begin{array}{l}\text { Carl Niehaus's lies seem to know no } \\
\text { end. }\end{array}$ & $\begin{array}{l}\text { Nog 'n string leuens deur } \\
\text { Niehaus het gister bekend } \\
\text { geword. }\end{array}$ \\
\hline No addition & $\begin{array}{l}\text { Added to end of article: } \\
\text { On Tuesday The Star reported that } \\
\text { Cheryl Clur, owner of the Let's Travel } \\
\text { travel agency in East London, said that } \\
\text { Niehaus had defrauded her by } \\
\text { convincing her to organise him a free } \\
\text { holiday in Mauritius. } \\
\text { He told her he had leukaemia and that } \\
\text { he needed to recover after receiving } \\
\text { chemotherapy. She lost R90 000. } \\
\text { At the time of publication, Niehaus's } \\
\text { CV was still available on LitNet. }\end{array}$ & Beeld, 2009/02/17 \\
\hline
\end{tabular}


Another article on Niehaus also carries a much more negative heading on the Internet. In this same article, the ANC is repudiated for not taking stronger steps against Niehaus. In the Afrikaans text, the utterance is softened by using the passive voice, whereas the English active version seems much more factual:

\begin{tabular}{|l|l|l|}
\hline \multicolumn{1}{|c|}{ Afrikaans print newspaper } & \multicolumn{1}{|c|}{ English News24 } & \multicolumn{1}{c|}{ Original Afrikaans } \\
\hline $\begin{array}{l}\text { Eviction order maybe soon for } \\
\text { Niehaus }\end{array}$ & Niehaus to be kicked out of home & $\begin{array}{l}\text { Uitsettingsbevel dalk gou vir } \\
\text { Niehaus }\end{array}$ \\
$\begin{array}{l}\text { "The party can't distinguish } \\
\text { right from wrong and it } \\
\text { becomes far too easy to excuse } \\
\text { criminal actions based on the } \\
\text { perception that ANC members } \\
\text { should be subjected to lower } \\
\text { moral standards than the rest } \\
\text { of South Africa." }\end{array}$ & $\begin{array}{l}\text { "The party can't distinguish right from } \\
\text { wrong and it becomes far too easy to } \\
\text { excuse criminal actions based on the } \\
\text { perception that lower moral } \\
\text { standards are valid for ANC } \\
\text { members than for the rest of South } \\
\text { ffrica." }\end{array}$ & $\begin{array}{l}\text { verkeerd onderskei nie en dit } \\
\text { word alte maklik om misdadige } \\
\text { optrede te verskoon op grond van } \\
\text { die idee dat ANC-lede aan 'n } \\
\text { laer morele standaard } \\
\text { onderwerp moet word as die } \\
\text { res van Suid-Afrika." }\end{array}$ \\
\hline
\end{tabular}

In one article that describes South Africans' views regarding gay marriage, the strong conservative outlook apparent in the ST is minimized in the TT. Interestingly enough, however, the fact that black South Africans did not tolerate gays was strengthened in the News 24 text. South Africa as a country was placed in a better light, but black people were placed in a more negative light:

\begin{tabular}{|c|c|c|}
\hline Afrikaans print newspaper & English News24 & Original Afrikaans \\
\hline $\begin{array}{l}\text { Being gay is wrong, } 80 \% \text { here } \\
\text { say }\end{array}$ & $80 \%$ of SA says no to gays & $\begin{array}{l}\text { Gaywees is verkeerd, sê } 80 \% \\
\text { hier }\end{array}$ \\
\hline $\begin{array}{l}\text { More than } 80 \% \text { of the } \\
\text { population aged } 16 \text { years and } \\
\text { above believes sex between two } \\
\text { men or two women "always to } \\
\text { be wrong". }\end{array}$ & $\begin{array}{l}\text { More than } 80 \% \text { of the population aged } \\
16 \text { years and above expressed the view } \\
\text { that sex between two men or two } \\
\text { women could be considered "always } \\
\text { wrong". }\end{array}$ & $\begin{array}{l}\text { Meer as } 80 \% \text { van die bevolking } \\
\text { bo die ouderdom van } 16 \text { glo } \\
\text { seks tussen twee mans of twee } \\
\text { vroue is "altyd verkeerd". }\end{array}$ \\
\hline $\begin{array}{l}\text { Black people were more } \\
\text { intolerant of homosexuality than } \\
\text { white or coloured people, as } \\
\text { well as rural inhabitants and } \\
\text { people with little schooling. }\end{array}$ & $\begin{array}{l}\text { Black people were more intolerant of } \\
\text { homosexuality than white or coloured } \\
\text { people } \emptyset \text {. }\end{array}$ & $\begin{array}{l}\text { Swart mense was meer } \\
\text { onverdraagsaam as wit en bruin } \\
\text { mense, asook landelike } \\
\text { inwoners en mense met min } \\
\text { skoolopleiding. }\end{array}$ \\
\hline & & Beeld, 2008/12/09 \\
\hline
\end{tabular}

\subsection{Nuus24/Netwerk24 - English into Afrikaans}

Could this be commercial? Maybe News24 only wants to lure more readers away from their opposition, International News Online (IOL), by means of increased sensationalism, almost like 
the tabloid press. Baker (2006:106) states that the tabloid press in most countries tends to exaggerate sensational aspects of public narratives in a bid to improve the newspaper's circulation. The changes described above cannot all be ascribed to an ideological agenda. If this were the case, the same recreation processes would apply in the reworking of news reports in the English print media for the Afrikaans Internet platform Nuus24/Netwerk24. One would expect a much more negative image of post-1994 South Africa, where issues of crime, politics and racial issues are intensified during the transediting process. To investigate this, 50 ideologically-coloured news reports were chosen, with the English ST in the print media and the Afrikaans TT as it appeared on the Internet as part of the news coverage by Nuus24/Netwerk24.

All the English reports were substantially shortened for Nuus24/Netwerk24. The shortened reports consisted mainly of a paraphrase in Afrikaans of the original English print report, but with a comment to "click here for the complete report" with a link to the complete report in the Internet version of the original newspaper.

\subsubsection{Headings}

Most of the headings were adapted. In only three cases are the Afrikaans headings a direct translation of the English, namely:

\begin{tabular}{|c|c|}
\hline Action expected on Zuma's bully bodyguards & $\begin{array}{c}\text { Stappe kom teen Zuma se boelie-wagte } \\
\text { Nuus } 24,2010 / 03 / 18 \\
\end{array}$ \\
\hline Zuma shows Simelane who's boss & Zuma wys Simelane wie's baas \\
\hline DA wins two of three by-elec & $\begin{array}{l}\text { DA wen twee derdes in KZN-tussenverkiesing } \\
\text { Nuus } 24,2010 / 05 / 06\end{array}$ \\
\hline
\end{tabular}

In the following eight examples, the Afrikaans headings are more explicit and sometimes also less euphemistic than the English ones:

\begin{tabular}{|l|l|l|}
\hline \multicolumn{1}{|c|}{ English print newspaper } & \multicolumn{1}{|c|}{ Afrikaans Nuus24 } & \multicolumn{1}{c|}{ Original Afrikaans } \\
\hline Now Shaka statue must go & $\begin{array}{l}\text { Shaka statue not good enough for } \\
\text { Zulu king }\end{array}$ & $\begin{array}{l}\text { Shaka-standbeeld nie goed } \\
\text { genoeg vir Zoeloe-koning }\end{array}$ \\
\hline Thabo Mbeki's Shaik-down & $\begin{array}{l}\text { Mbeki advises Shaik on business } 2010 / 06 / 02 \\
\text { with the ANC }\end{array}$ & $\begin{array}{l}\text { Mbeki adviseer Shaik oor } \\
\text { besigheid met die ANC }\end{array}$ \\
\hline Khoza's daughter speaks out & $\begin{array}{l}\text { Khoza's daughter denies Zuma love- } \\
\text { child }\end{array}$ & $\begin{array}{l}\text { Khoza se dogter ontken Zuma- } \\
\text { liefdeskind }\end{array}$ \\
\hline Malema dares Zuma & Zuma worse than Mbeki - Malema & $\begin{array}{l}\text { Zuma erger as Mbeki - } \\
\text { Malema }\end{array}$ \\
\hline
\end{tabular}




\begin{tabular}{|l|l|l|}
\hline Shiceka: Hey big spender & Minister apparently lies in CV & Minister jok glo op CV \\
\hline Pick n Pay workers to strike & $\begin{array}{l}\text { Workers of Pick n Pay will also be on } 24,2010 / 05 / 21 \\
\text { strike }\end{array}$ & $\begin{array}{l}\text { Werkers van Pick n Pay gaan } \\
\text { ook staak }\end{array}$ \\
\hline $\begin{array}{l}\text { Malema's assets could be } \\
\text { attached today }\end{array}$ & Malema: Bailiff will not take my stuff $24,2010 / 08 / 31$ \\
\hline $\begin{array}{l}\text { Journo forced to delete } \\
\text { pictures }\end{array}$ & $\begin{array}{l}\text { Zuma security believed to attack } \\
\text { journalist }\end{array}$ & $\begin{array}{l}\text { Matema: Balju sal nie my goed } \\
\text { joernalis aan }\end{array}$ \\
\hline
\end{tabular}

As the data show, however, the Afrikaans headings are in most cases more neutral and more euphemistic; in other words, less negative towards the ANC government and its allies:

\begin{tabular}{|c|c|c|}
\hline English print newspaper & Afrikaans Nuus24 & Original Afrikaans \\
\hline $\begin{array}{l}\text { Mugabe celebrates birthday amid } \\
\text { distress }\end{array}$ & Mugabe gives party & $\begin{array}{l}\text { Mugabe hou partytjie } \\
\qquad \text { Nuus } 24,2010-02-27\end{array}$ \\
\hline Cop bungle may boost Jub Jub & Police negligence can help Jub Jub & $\begin{array}{l}\text { Polisie se nalatigheid kan } \\
\text { Jub Jub help } \\
\qquad \text { Nuus } 24,2010 / 05 / 12\end{array}$ \\
\hline Defiant Vavi won't say sorry & Vavi refuses to say sorry & $\begin{array}{l}\text { Vavi weier om jammer te sê } \\
\text { Nuus } 24,2010 / 06 / 11\end{array}$ \\
\hline $\begin{array}{l}\text { Inside an ANC cover-up } \\
\text { The Mandela Archives: The } \\
\text { billionaire, the bureaucrat and the } \\
\text { missing party funds }\end{array}$ & $\begin{array}{l}\text { Letter shows top ANC members } \\
\text { investigated for fraud }\end{array}$ & $\begin{array}{l}\text { Briewe wys top ANC-lede } \\
\text { is vir bedrog ondersoek } \\
\qquad \text { Nuus } 24,2010 / 08 / 22 \\
\end{array}$ \\
\hline Don't ignore SA's painful history & Don't ignore the past, says Motlanthe & $\begin{array}{l}\text { Moenie die verlede } \\
\text { ignoreer, sê Motlanthe } \\
\qquad \text { Nuus } 24,2010 / 06 / 02\end{array}$ \\
\hline $\begin{array}{l}\text { Reporter: I was paid to pursue } \\
\text { Rasool agenda }\end{array}$ & Reporter was spin-doctor for Rasool & $\begin{array}{l}\text { Joernalis was beeldpoetser } \\
\text { vir Rasool } \\
\qquad \text { Nuus } 24,2010 / 06 / 30\end{array}$ \\
\hline
\end{tabular}




\begin{tabular}{|c|c|c|}
\hline \multirow[t]{2}{*}{ Madiba confessed to immoral life } & Book reveals Mandela's wild years & $\begin{array}{l}\text { Boek ontbloot Mandela se } \\
\text { wilde jare }\end{array}$ \\
\hline & & Nuus $24,2010 / 05 / 31$ \\
\hline \multirow[t]{2}{*}{ Outcry about $R 5 \mathrm{~m}$ soccer tickets } & $\begin{array}{l}\text { Government buys World Cup tickets } \\
\text { for R5 million }\end{array}$ & $\begin{array}{l}\text { Regering koop R5 miljoen } \\
\text { se WB-kaartjies }\end{array}$ \\
\hline & & Nuus $24,2010 / 06 / 03$ \\
\hline \multirow[t]{2}{*}{$\begin{array}{l}\text { Top Hawks officer accused of racial } \\
\text { slur }\end{array}$} & Top Hawk in racial uproar & $\begin{array}{l}\text { Top-Valk in rasseherrie } \\
\text { gedompel }\end{array}$ \\
\hline & & Nuus $24,2010 / 05 / 13$ \\
\hline \multirow[t]{2}{*}{ MaNtuli pays for cheating on Zuma } & $\begin{array}{l}\text { Zuma wife apparently punished } \\
\text { earlier }\end{array}$ & $\begin{array}{l}\text { Zuma-vrou glo vroeër } \\
\text { gestraf }\end{array}$ \\
\hline & & Nuus $24,2010 / 06 / 04$ \\
\hline $\begin{array}{l}\text { Gauteng's head of prisons guilty of } \\
\text { fraud }\end{array}$ & Female head of prisons in hot water & $\begin{array}{r}\text { Vroulike tronkhoof in sop } \\
\text { Nuus } 24,2010 / 10 / 13 \\
\end{array}$ \\
\hline \multirow[t]{2}{*}{20 miners executed } & $\begin{array}{l}\text { Newspaper makes horror discovery } \\
\text { at controversial mine }\end{array}$ & $\begin{array}{l}\text { Koerant maak gru-vonds } \\
\text { by omstrede myn }\end{array}$ \\
\hline & & Nuus $24,2010 / 08 / 12$ \\
\hline
\end{tabular}

\subsubsection{Reports}

Headings pave the way for what is expected in the reports themselves, or they literally frame the narrative. As already said, the Afrikaans Internet versions all consist of a much-shortened paraphrase of the original English print report. The paraphrases of almost all of the 50 investigated reports lead to a much more neutral and sometimes even euphemistic read compared to the English print reports:

\begin{tabular}{|l|l|l|}
\hline \multicolumn{1}{|c|}{ English print newspaper } & \multicolumn{1}{|c|}{ Afrikaans Nuus24 } & \multicolumn{1}{c|}{ Original Afrikaans } \\
\hline police grossly irresponsible; & Omission; & glips \\
\hline $\begin{array}{l}\text { blood test blunder } \\
\text { slip-up }\end{array}$ & Nuus24,2010/05/12 \\
\hline $\begin{array}{l}\text { an online journalist at } 702 \\
\text { was accosted by the SAPS VIP } \\
\text { Protection Unit; } \\
\text { three of them threatened me }\end{array}$ & Omission; & Omission;
\end{tabular}




\begin{tabular}{|c|c|c|}
\hline $\begin{array}{l}\text { were investigated for allegedly } \\
\text { colluding to enrich themselves } \\
\text { by using ANC funds }\end{array}$ & they allegedly used ANC funds & $\begin{array}{l}\text { hulle na bewering ANC } \\
\text { fondse gebruik het } \\
\qquad \text { Nuus } 24,2010 / 08 / 22\end{array}$ \\
\hline $\begin{array}{l}\text { advised Shaik to set up a } \\
\text { business empire - specifically } \\
\text { for the benefit of the cash- } \\
\text { strapped ruling party }\end{array}$ & $\begin{array}{l}\text { advised Shaik to set up a business } \emptyset \\
\text { specifically for the benefit of the } \varnothing \text { ruling } \\
\text { party }\end{array}$ & $\begin{array}{l}\text { Shaik aangeraai het om 'n } \\
\text { besigheid op te bou } \varnothing \\
\text { spesifiek met die doel om die } \\
\emptyset \text { regerende party te } \\
\text { bevoordeel. } \\
\text { Nuus } 24,2010 / 08 / 15\end{array}$ \\
\hline odious acts of the past & injustices of the past & $\begin{array}{l}\text { onregte van die verlede } \\
\qquad \text { Nuus } 24,2010 / 06 / 02 \\
\end{array}$ \\
\hline $\begin{array}{l}\text { South Africans may have } \\
\text { come to terms with President } \\
\text { Jacob Zuma's infidelity, but a } \\
\text { new book to be released next } \\
\text { month about Nelson Mandela } \\
\text { claims the country's first } \\
\text { democratic president was no } \\
\text { saint either }\end{array}$ & $\begin{array}{l}\text { Omission. A new book about Nelson } \\
\text { Mandela makes it clear that the sanctified } \\
\text { leader had no innocent love-life }\end{array}$ & $\begin{array}{l}\text { 'n Nuwe boek oor oud- } \\
\text { president Nelson Mandela } \\
\text { maak dit duidelik dat dié } \\
\text { opgehemelde leier glad nie 'n } \\
\text { onskuldige liefdeslewe gehad } \\
\text { het nie. } \\
\qquad \text { Nuus } 24,2010 / 05 / 31\end{array}$ \\
\hline $\begin{array}{l}\text { A political analyst has warned } \\
\text { of the chilling effect the } \\
\text { actions of Julius Malema could } \\
\text { have on democracy in South } \\
\text { Africa; } \\
\text { Malema's use of policemen to } \\
\text { crush his opposition }\end{array}$ & $\begin{array}{l}\text { A political analyst has warned that the } \\
\text { actions of youth leader Julius Malema } \\
\text { could be "dangerous" for democracy; } \\
\text { the controversial Malema has used } \\
\text { policemen to remove his opposition }\end{array}$ & $\begin{array}{l}\text { 'n Politieke analis het } \\
\text { gewaarsku dat die optrede } \\
\text { van die ANC Jeugliga-leier } \\
\text { Julius Malema tydens die liga } \\
\text { se konferensie in Makhado in } \\
\text { Limpopo, 'gevaarlik' kan } \\
\text { wees vir demokrasie } \\
\text { omstrede Malema polisie } \\
\text { gebruik om sy teenstanders } \\
\text { uit die weg te ruim }\end{array}$ \\
\hline & & Nuus $24,2010 / 06 / 18$ \\
\hline $\begin{array}{l}\text { the news of Winnie Mandela's } \\
\text { verbal attack on her ex- } \\
\text { husband, Nelson Mandela; }\end{array}$ & $\begin{array}{l}\text { Winnie Mandela's commentary on Nelson } \\
\text { Mandela }\end{array}$ & $\begin{array}{l}\text { Mandela se kommentaar oor } \\
\text { Nelson Mandela } \\
\qquad \text { Nuus } 24,2010 / 03 / 10 \\
\end{array}$ \\
\hline $\begin{array}{l}\text { with the } S A B C \text { splurging } \\
R 3.3 m \text { on more than } 2,000 \\
\text { tickets }\end{array}$ & $\begin{array}{l}\text { while the SABC spent } \mathrm{R} 3,3 \text { million on } \\
\text { more than } 2000 \text { tickets }\end{array}$ & $\begin{array}{l}\text { terwyl die SABC R3,3 } \\
\text { miljoen op meer as } 2000 \\
\text { kaartjies spandeer het } \\
\qquad \text { Nuus } 24,2010 / 06 / 03\end{array}$ \\
\hline
\end{tabular}




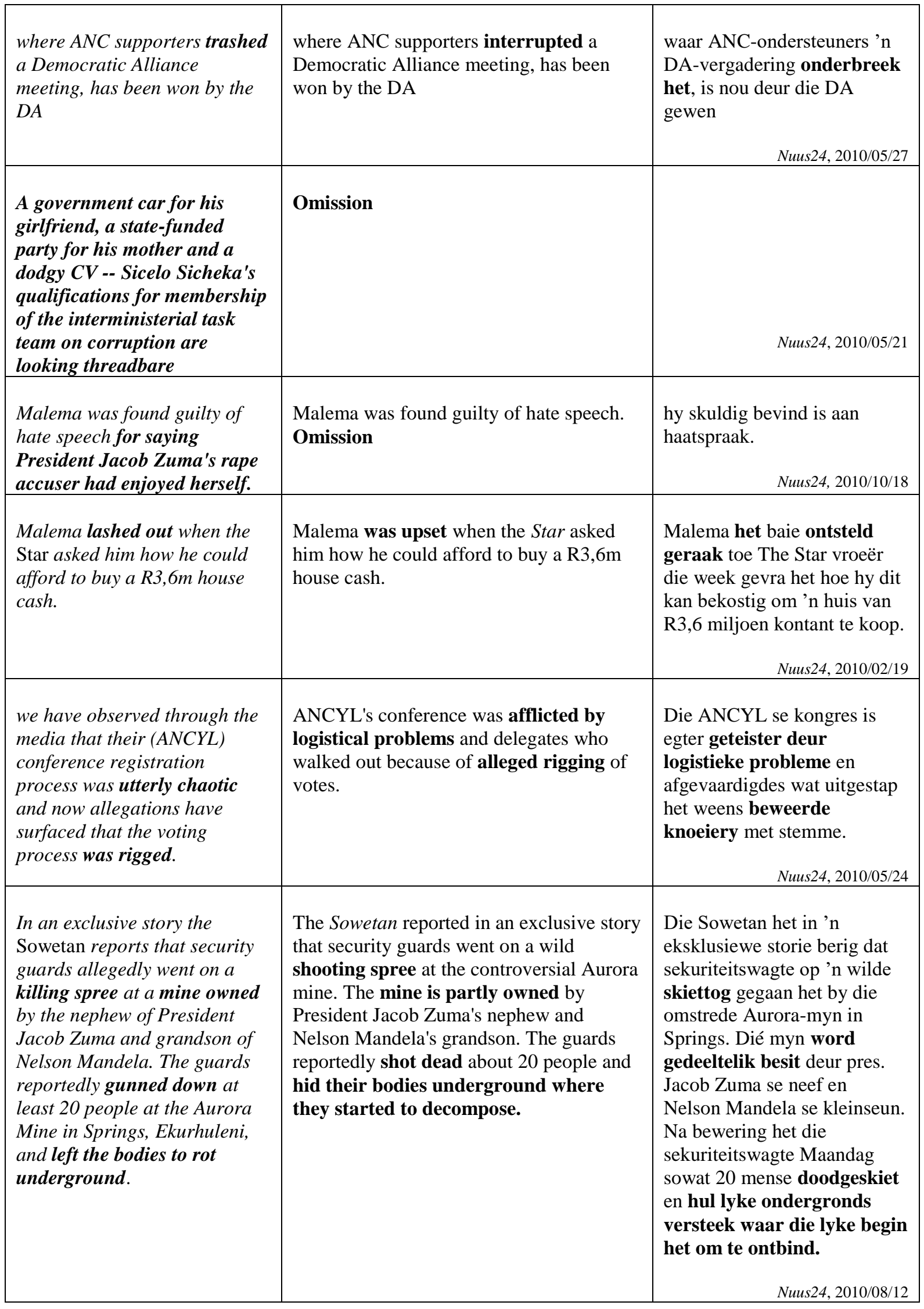




\begin{tabular}{|l|l|l|}
\hline $\begin{array}{l}\text { corrupt police officers have no } \\
\text { place in the South African } \\
\begin{array}{l}\text { Police Service (SAPS) and they } \\
\text { will be rooted out. }\end{array}\end{array}$ & $\begin{array}{l}\text { corrupt police officers have no place in the } \\
\text { South African Police Service (SAPS) and } \\
\text { they will be removed. }\end{array}$ & $\begin{array}{l}\text { korrupte polisiebeamptes } \\
\text { geen plek in die Suid- } \\
\text { Afrikaanse polisiediens } \\
\text { (SAPD) het nie en dat hulle } \\
\text { verwyder sal word. } \\
\text { Nuus24, 2010/10/20 }\end{array}$ \\
\hline $\begin{array}{l}\text { The problem is getting worse } \\
\text { and worse and it obviously } \\
\text { places the lives of ordinary } \\
\begin{array}{l}\text { South Africans at a huge risk. } \\
\text { The problem is only getting worse and it }\end{array}\end{array}$ & $\begin{array}{l}\text { Thlaces the lives of ordinary South } \\
\text { Africans in danger. }\end{array}$ & $\begin{array}{l}\text { Die probleem raak net erger } \\
\text { en dit plaas die lewens van } \\
\text { gewone Suid-Afrikaners in } \\
\text { gevaar }\end{array}$ \\
\hline
\end{tabular}

In only one report, commenting on election results, the Afrikaans paraphrase seems more definite than the English print report:

\begin{tabular}{|l|l|l|}
\hline \multicolumn{1}{|c|}{ English print newspaper } & \multicolumn{1}{|c|}{ Afrikaans Nuus24 } & \multicolumn{1}{c|}{ Original Afrikaans } \\
\hline $\begin{array}{l}\text { The ANC polled } 37.7 \text { percent, } \\
\text { The ANC polled only 37.7 percent. }\end{array}$ & $\begin{array}{l}\text { Die ANC het slegs } 37.7 \% \text { van } \\
\text { die stemme verkry. } \\
\text { Nuus24, 2010/05/27 }\end{array}$ \\
\hline $\begin{array}{l}\text { The } \text { The ANC has not won } \text { a ward } \\
\text { in the Western Cape since the } \\
\text { April } 2009 \text { national election. }\end{array}$ & $\begin{array}{l}\text { The ANC has not won a single ward in the } \\
\text { Western Cape since the April 2009 } \\
\text { national election. }\end{array}$ & $\begin{array}{l}\text { Die ANC het sedert die } \\
\text { verkiesing in April 2009, nog } \\
\text { nie 'n enkele wyk in die Wes- } \\
\text { Kaap gewen nie. } \\
\text { Nuus24, 2010/05/27 }\end{array}$ \\
\hline
\end{tabular}

If the content is taken into account, the reporting is not on something negative done by the ANC or one of the party members, but on the fact that the ANC did not perform well in a recent election. The latter is then emphasised in the Afrikaans version.

To summarise, this investigation produced the same results as the previous investigation: the reports for the Afrikaans readers are more likely to be framed in a less negative, less intensified way than the versions meant for the English readers. This occurs regardless of the news genre, i.e. print media or Internet platform. These results also prove that the previous investigation's finding of a more negative, more intensified reframing of Afrikaans reports in the print media for the English Internet reader is not due to the wish to generate more sensation, but is linked to the language and/or cultural group: the same less negative, less intensified way of framing was found in the Afrikaans data, although the Afrikaans stories now appeared on the Internet platform. 


\subsection{News24 - English into English}

To see whether the ideological reframing only occurs in interlingual situations, 50 ideologically-coloured news reports were investigated. These were English STs taken from the two print newspapers, City Press and The Witness, and their English TTs as they appeared on the Internet as part of the news coverage of News24.

On a more basic level, notions of place, space and time were reconfigured in the process of transediting the texts for the Internet. This led to somewhat shortened texts throughout, by omitting all references to specific times, dates and days of the week. Also, all titles of persons referred to were omitted, and all denominations were abbreviated, e.g. billion vs. bn; million vs. $m$. In my opinion, some of these omissions produced better journalism, in the sense that meaningless and insignificant information, e.g. quotations stating "no comment", was left out.

Explicitation is another strategy applied to the reframing of the print newspaper texts for the News24 reader, from which one could deduce that the Internet newsreader might not be as familiar with the South African situation as the reader of print newspapers. Acronyms used in print newspapers were either

- written out the first time they were used:

Cosatu vs. Congress of South African Trade Unions;

- labelled by means of brackets:

$B E E$ vs. BEE (black economic empowerment)

$N W C$ [national working committee]; or

- generic words were added after e.g. titles of newspapers:

Star vs. Star newspaper.

The layout in the Internet version was changed mostly in order to provide an easier read: paragraphs were adapted into single-sentence paragraphs, and subheadings were inserted so that the reader could get the gist of the report by only reading the heading and the subheadings.

\subsubsection{Headings}

Some print newspaper headings tended to be more metaphorical than their Internet counterparts, which tended to be more descriptive and therefore more neutral:

\begin{tabular}{|l|l|}
\hline \multicolumn{1}{|c|}{ English print newspaper } & \multicolumn{1}{c|}{ English News24 } \\
\hline UIF to cushion the fall & UIF plans to extend benefit period \\
\hline Zuma: business not the BEE-all of empowerment & Zuma concerned about BEE \\
\hline Lifeline for black farmers & KZN to rescue failed land reform farms \\
\hline Zuma fires fong con & Zuma fires conman \\
\hline
\end{tabular}


Most of the adaptations leading to a more ideological reframing were found in the recreation of the headings. It seems that the headings used in print newspapers were more scathing and more explicit in their criticism than those used on News24. Some of these harsher headings were also metaphoric, whereas the more descriptive headings tended to be more neutral:

\begin{tabular}{|l|l|}
\hline \multicolumn{1}{|c|}{ English print newspaper } & \multicolumn{1}{c|}{ English News24 } \\
\hline Cosatu bleeds & Cosatu to stem member exodus \\
\hline Malema's company scores - again & Malema got four deals in one month \\
\hline Business leaders rule out sympathy strikes & Doubts over sympathy strike \\
\hline State forges a bigger role in the economy & Business uneasy over govt intervention \\
\hline Manuel's letter to Manyi leaves ANCYL fuming & Manuel a right-wing force, says ANCYL \\
\hline How did Guptas qualify for BEE steel deal? & Guptas under scrutiny \\
\hline 'Strange time' for Mthembu to be drunk & ANC looking into Mthembu arrest \\
\hline $\begin{array}{l}\text { Agliotti: Friendship, business behind Selebi } \\
\text { payments }\end{array}$ & Selebi payments 'for friendship' \\
\hline
\end{tabular}

There were some exceptions where the Internet headings were found to be harsher and more explicit than those of the reports in print newspapers, albeit not markedly so:

\begin{tabular}{|l|l|}
\hline \multicolumn{1}{|c|}{ English print newspaper } & \multicolumn{1}{c|}{ English News24 } \\
\hline Mining houses still fail to meet BEE targets & Miners fail to meet BEE targets \\
\hline Firms are failing black youth & Firms fail black youth \\
\hline 'AWB man' threatened Zuma with snipers & 'AWB man' threatens to kill Zuma \\
\hline Hitting them where it hurts & Manyi: 'I'll hit where it hurts' \\
\hline
\end{tabular}

\subsubsection{Reports}

Apart from the textual changes already discussed, the content of the Internet reports is identical to that of the print reports. In only two reports did I find adaptations that could be attributed to ideological motivation. In the first example quoted here, a sentence was added at the opening 
of the Internet report. This immediately reframes the report in a more negative way, although the heading suggests a rather positive report.

\begin{tabular}{|l|l|}
\hline \multicolumn{1}{|c|}{ English print newspaper } & \multicolumn{1}{c|}{ English News24 } \\
\hline Black directors arrive on JSE & Black directors arrive on JSE \\
\hline$\varnothing$ & $\begin{array}{l}\text { If SA continues to neglect the plight of the jobless } \\
\text { the country will go the way of Egypt, according to a } \\
\text { Rhodes University lecturer. }\end{array}$ \\
\hline
\end{tabular}

In the other report, which deals with the killing of the AWB leader Eugene Terre'Blanche, the Internet variation appears more sympathetic towards one of the accused than the print version. Some lexical items were added to the Internet version. The heading was also slightly adapted:

\begin{tabular}{|l|l|}
\hline \multicolumn{1}{|c|}{ English print newspaper } & \multicolumn{1}{|c|}{ English News24 } \\
\hline $\begin{array}{l}\text { Grisly details of Terre'Blanche murder } \\
\begin{array}{l}\text { Chris Mahlangu (27) listened impassively as } \\
\text { investigating officer Tsietsi Mano testified how } \\
\text { the brutality of the Easter weekend murder } \\
\text { had disturbed him. }\end{array}\end{array}$ & $\begin{array}{l}\text { Chris Mahlangu, 27, a slender man, listened impassively as } \\
\text { investigating officer Tsietsi Mano testified how the brutality } \\
\text { of the Easter Weekend murder had disturbed him. }\end{array}$ \\
\hline $\begin{array}{l}\text { "Accused number two (the minor) said his } \\
\text { (Mahlangu's) intention was to dismember - } \\
\text { but thereafter he left it, said Mano. }\end{array}$ & $\begin{array}{l}\text { "Accused number two (the youth) said his (Mahlangu's) } \\
\text { intention was to dismember - but thereafter he left it," said } \\
\text { Mano. }\end{array}$ \\
\hline
\end{tabular}

All in all, it seems as though the reworked Internet versions of the English print reports are less harsh than their print counterparts. Once again, this defies the suggestion that Internet reporting tends to exaggerate sensational aspects of public narratives to increase readership. The opposite is proved here.

\subsection{Nuus24/Netwerk24 - Afrikaans into Afrikaans}

To complete this investigation, I scrutinised Afrikaans print-newspaper reports and their corresponding items on the Afrikaans Internet platform, Nuus24/Netwerk24 - also an intralingual situation. Fifty ideologically-coloured news reports were chosen with the Afrikaans STs in the print media and the Afrikaans TTs as they appeared on the Internet as part of the news coverage of Nuus24/Netwerk24.

Almost no changes were found between the two versions; the only adaptations were that the reports were shortened for the Internet by the omission of all titles of people and most adverbs and nouns referring to specific dates. Adverbs like yesterday, today and tomorrow were either omitted or rephrased into nouns, e.g. Monday. 
Regarding the layout, the same was found for the intralingual English-into-English adaptations, in that the Internet version was mostly changed to provide an easier read: paragraphs were adapted into single-sentence paragraphs and subheadings were inserted so that the reader could get the gist of the report by only reading the heading and subheadings.

\subsubsection{Headings}

Most headings were shortened considerably for the Internet version. Other than that, two cases were found where the headings in Nuus24/Netwerk 24 were more explicit, which led to a harsher impression:

\begin{tabular}{|c|c|c|c|}
\hline $\begin{array}{c}\text { Afrikaans print } \\
\text { newspaper }\end{array}$ & Original Afrikaans & Afrikaans Nuus24/Netwerk24 & Original Afrikaans \\
\hline $\begin{array}{l}\text { Billy goes farming in } \\
\text { Zim }\end{array}$ & $\begin{array}{l}\text { Billy gaan in Zim } \\
\text { boer } \\
\text { Beeld, 2010/01/14 }\end{array}$ & $\begin{array}{l}\text { Controversial businessman } \\
\text { obtains land in Zim }\end{array}$ & $\begin{array}{l}\text { Omstrede sakeman kry } \\
\text { grond in Zim } \\
\qquad \text { Nuus } 24,2010 / 01 / 14\end{array}$ \\
\hline $\begin{array}{l}\text { ANC VIPs spring to } \\
\text { attention when Malema } \\
\text { phones }\end{array}$ & $\begin{array}{l}\text { ANC-hoës spring op } \\
\text { aandag toe Malema } \\
\text { bel } \\
\quad \text { Rapport, 2009/11/02 }\end{array}$ & $\begin{array}{l}\text { Malema apparently scolded } \\
\text { traffic police }\end{array}$ & $\begin{array}{l}\text { Malema skel glo } \\
\text { verkeersbeamptes uit } \\
\text { Nuus } 24,2009 / 11 / 01\end{array}$ \\
\hline Malema uses blue light & $\begin{array}{l}\text { Malema gebruik } \\
\text { blou lig } \\
\text { Beeld, 2009/11/05 }\end{array}$ & Malema speeds with blue light & $\begin{array}{l}\text { Malema jaag met blou } \\
\text { lig } \\
\text { Nuus } 24,2009 / 11 / 05\end{array}$ \\
\hline
\end{tabular}

In one case, a heading seems more euphemistic in the Internet version because of an added adverb:

\begin{tabular}{|l|l|l|l|}
\hline \multicolumn{1}{|c|}{$\begin{array}{c}\text { Afrikaans print } \\
\text { newspaper }\end{array}$} & \multicolumn{1}{|c|}{$\begin{array}{c}\text { Original } \\
\text { Afrikaans }\end{array}$} & Afrikaans Nuus24/Netwerk24 & Original Afrikaans \\
\hline $\begin{array}{l}\text { Julius Malema cheats } \\
\text { taxman }\end{array}$ & $\begin{array}{l}\text { Julius Malema kul } \\
\text { Jan Taks }\end{array}$ & $\begin{array}{l}\text { Julius Malema apparently cheats } \\
\text { taxman } \\
\text { Rapport, 2010/03/10 }\end{array}$ & $\begin{array}{l}\text { Malema kul glo Jan } \\
\text { Taks }\end{array}$ \\
\hline
\end{tabular}

\subsubsection{Reports}

Apart from the few textual changes already discussed, the contents of the Afrikaans Internet reports are identical to those of the Afrikaans print reports. The situation is the same as that of the intralingual translation for English. In the 50 reports investigated, I found only one adaptation that could be attributed to an ideological motivation, where a direct quotation from the print version was omitted at the end of the Internet report. This led to a less harsh report, although the heading in the Internet text was perceived as being more negative towards Malema: 


\begin{tabular}{|c|c|c|c|}
\hline $\begin{array}{c}\text { Afrikaans print } \\
\text { newspaper }\end{array}$ & Original Afrikaans & $\begin{array}{c}\text { Afrikaans } \\
\text { Nuus24/Netwerk24 }\end{array}$ & Original Afrikaans \\
\hline $\begin{array}{l}\text { ANC VIPs spring to } \\
\text { attention when Malema } \\
\text { phones }\end{array}$ & $\begin{array}{l}\text { ANC-hoës spring op } \\
\text { aandag toe Malema bel } \\
\qquad \text { Rapport, 2009/11/02 }\end{array}$ & $\begin{array}{l}\text { Malema apparently } \\
\text { scolded traffic police }\end{array}$ & $\begin{array}{l}\text { Malema skel glo } \\
\text { verkeersbeamptes uit } \\
\text { Nuus } 24,2009 / 11 / 01\end{array}$ \\
\hline $\begin{array}{l}\text { "Who do you think you } \\
\text { are? Don't you realise I } \\
\text { am Julius, president of } \\
\text { the Youth League? I } \\
\text { know some of you hate } \\
\text { me." } \\
\text { - Mr Julius Malema to } \\
\text { traffic police. }\end{array}$ & $\begin{array}{l}\text { "Wie dink julle is julle? } \\
\text { Besef julle nie ek is } \\
\text { Julius, president van die } \\
\text { jeugliga, nie? Ek weet } \\
\text { van julle haat my." } \\
\text { - mnr. Julius Malema } \\
\text { aan verkeersbeamptes } \\
\text { Rapport, 2009/11/02 }\end{array}$ & Omitted & \\
\hline
\end{tabular}

Because of the very few differences found between the Afrikaans print and Afrikaans Internet reports, no argument could be made for a more sensational reframing of Internet reports by the editorial team dealing with these intralingual transeditings.

\section{Conclusion}

Baker (2006:19) emphasises that the way in which texts are framed focuses on the power and function of narratives, rather than their structural make-up. The emphasis is therefore on the fact that narrative shapes people's views of rationality, of objectivity, of morality and their conceptions of themselves and others. It is also important to consider the fact that I, as the researcher, am not unaffected by the narratives that form my own sentiments of the world and the events that shape my life. Baker reminds scholars that "[t]he ethical systems by which we judge cultural narratives are themselves cultural narratives" (Ryan 2003 in Baker 2006:129). As such, a similar investigation by other researchers might result in different findings.

It is therefore important to realise the responsibility the editing team has in this news environment where they have the power to shape the minds of their readership by means of the narratives they create. My research has found a definite reframing of information for the English and Afrikaans readerships, regardless of the genre of media platform used; in other words, frame ambiguity does occur between these two readerships. For the Afrikaans readership, the reports were phrased in more neutral terms, or they were less sensational, less harsh and less negative than their English counterparts. Bear in mind that all the print newspapers and the two Internet news platforms belong to the same publishing house, Media24: the different treatment of the news aimed at the two language groups thus has to be a conscious in-house decision. The ideological component is one of the main role-players in the manipulation of texts, and here it seems to be the main reason for the reframing of the media reports for the readerships of the two language groups. Ideology is seen to be the "grillwork of form, convention and belief which orders our actions" (Jameson in Lefevere 1992:16). Ideology also refers to ideas, value concepts and assumptions, which can be cultural or political and are related to the power and authority of persons and institutions in a specific society. Abdulla (in Aksoy 2001 in Feinauer 2008:222) 
mentions that ideology refers to the propositions and assumptions we hold consciously and unconsciously about ourselves which guide our actions (own emphasis).

This rechannelling of information for the English reader in News24 (mainly in interlingual transediting from Afrikaans into English) and for the Afrikaans reader in Nuus24/Netwerk24 (mainly in interlingual transediting from English into Afrikaans) could possibly be ascribed to the following: since the Afrikaans press was considered the official mouthpiece of the National Party and its infamous policy of apartheid, they do not want to come out too strongly in Afrikaans against ANC-ruled South Africa. Unburdened by this stigma, the English press especially a newspaper with a majority black readership and a black editor like City Press - has fewer reservations about painting a much bleaker picture of the news.

Another reason for the Afrikaans media to frame post-apartheid South Africa in a more positive way could be that many white Afrikaans citizens, especially males aged 45 and above, are feeling marginalised and vulnerable in post-apartheid South Africa. They have had to go through a profound psychological adaptation in making sense of their situation and function in a rapidly-changing environment. In a relatively short time, they have lost their position of power, control and authority. See Steyn (2001) for a description of the five dominant postapartheid narratives among white Afrikaans-speaking people, namely:

- $\quad$ still colonial after all these years;

- $\quad$ this shouldn't happen to a white person;

- don't think white, then it's all right;

- a whiter shade of white; or

- $\quad$ under African skies, or white, but not quite.

Therefore the Afrikaans media do not want to pour oil on the already-burning fire.

This research could and should be extended to include an investigation into the reframing - or lack thereof - of both Afrikaans and English print newspaper reports published on the isiZulu Internet news portal Izindaba News24, which also belongs to Media24. Further research could entail developing a model according to which this type of reframing can be done, or could determine whether existing models in Translation Studies could be applied. Compare here the use of Nord's looping model by Van Rooyen (2011) and Van Rooyen and Naudé (2009).

\section{References}

Average issue readership of newspapers and magazines-profile. 2009. Available online: http://www.saarf.co.za/AMPS/technicalreport-2009A/data\%20files/Amps/Tot-do1.pdf. (Accessed 20 March 2010).

Baker, M. 2006. Translation and conflict. A narrative account. London: Routledge.

Baker, M. 2007. Reframing conflict in translation. Social Semiotics 17(2): 151-169.

Bell, A. 1991. The language of news media. Oxford UK and Cambridge MA: Blackwell.

Bielsa, E. and S. Bassnett. 2009. Translation in global news. London and New York: Routledge. 
Bruner, J. 1991. The narrative construction of reality. Critical Inquiry 18(1): 1-21.

Chen, Y. 2009. The construction of 'self' and 'other' in transediting of news texts concerning political conflicts. Unpublished paper read at 3rd IATIS Conference, July 2009: Melbourne.

Fairclough, N. 1995. Media discourse. London: Arnold.

Feinauer, I. 2008. Hijacking the source text: The power of the translator. In B. LewandowskaTomasczyk and M. Thelen (eds.) Translation and meaning Part 8. Maastricht: University Press Maastricht. pp. 219-233.

Fisher, W.R. 1984. Narration as a human communication paradigm: The case of public moral agreement. Communication Monographs 51: 1-22.

Fisher, W.R. 1985. The narrative paradigm: In the beginning. Journal of Communication 35(4): 74-89.

Fisher, W.R. 1987. Human communication as narration: Toward a philosophy of reason, value, and action. Columbia: University of South Carolina Press.

Fox, O. 2009. The role of translation and interpretation in the shaping of a reader's view of world events: The press and the Falklands War. Unpublished paper read at 3rd IATIS Conference, July 2009: Melbourne.

Gambier, Y. 2006. Transformations in international news. In K. Conway and S. Bassnett. Translation in global news. Proceedings of the conference held at the University of Warwick, 23 June 2006. UK: University of Warwick.

Gopinathan, G. 2006. Translation, transcreation and culture. In T. Hermans (ed.) Translating others: Volume 1. Manchester: St Jerome. pp. 236-256.

History and Development, 2010. Naspers Company History. Available online: http://www.naspers.com/Company_History.cfm?content=2651\&intParentContentid.

(Accessed 21 February 2010).

Johnson, S. and A. Ensslin. 2007. Language in the media: Representation, identities, ideologies. London: Continuum.

Kang, J-H. 2007. Recontextualization of news discourse: A case study of translation of news discourse on North Korea. In S. Cunico and J. Munday (eds.) Translation and ideology: Encounters and clashes 13:2. Amsterdam: John Benjamins. pp. 219-242.

Lefevere, A. 1992. Translation, rewriting and the manipulation of literary fame. New York: Routledge.

Mediaclubsouthafrica, 2011. The press in South Africa Available online: http://www.mediaclubsouthafrica.com/index.php?option=com content\&view=article\&id=73 \%3Apress\&catid=36\%3Amedia_bg\&Itemid=54. (Accessed 22 May 2011).

Momberg, J. 2010. Personal e-mail correspondence with News24 editor-in-chief. 8 April 2010. 
Oldewage, H. 2011. Personal e-mail correspondence with Nuus24 editor-in-chief. 20 May 2011.

Somers, M.R. and G.D. Gibson. 1994. Reclaiming the epistemological "Other": Narrative and the social constitution of identity. In C. Calhoun (ed.) Social theory and the politics of identity. Oxford UK and Cambridge MA: Blackwell. pp. 37-99.

Steyn, M. 2001. Whiteness just isn't what it used to be: White identity in a changing South Africa. New York: University of New York Press.

Tymoczko, M. 2007. Enlarging translation. Empowering translators. Manchester: St Jerome Publishing.

Van Rooyen, M. and J.A. Naudé. 2009. A model for the translation of news agency texts (Sapa) for radio (OFM) news. Communicatio 35(2): 251-275.

Van Rooyen, M. 2011. A mediation model for the translation of radio news texts in a multicultural newsroom. Southern African Linguistics and Applied Language Studies 29(1): $17-29$. 